\title{
Questioning and Understanding in the Library: A Philosophy of Technology Perspective
}

\author{
Tim Gorichanaz \\ College of Computing \& Informatics, Drexel University \\ gorichanaz@drexel.edu, +1 (215) 895-1858
}

\begin{abstract}
This paper examines the history of epistemological conceptualizations of the library, considered as a technology. Drawing from Heidegger's philosophy, a technology is a way of human relating to the world. At its best, this relationship is in terms of belonging and understanding, but modern information technologies may not foster such aims very well. Heidegger links understanding to questioning; thus, this paper paper explores questioning in the library as a path to reorient the library more concertedly toward understanding. As a first stage in such work, this paper explores the history of questioning in the library. The library was originally conceived as an educational institution that afforded questioning, personal relationships and understanding. As time wore on, the library was transformed into something more like a business, where answers and information were provided as economic resources. This paper provides grounds for a renewed conceptualization of the library as a site for understanding and questioning. If the field is to reorient toward understanding, a deeper appreciation for questioning will be required.

Keywords: Heidegger, library history, philosophy of technology, understanding, questioning, reference interview
\end{abstract}




\section{Questioning and Understanding in the Library: \\ A Philosophy of Technology Perspective}

This paper discusses how the conceptualization of libraries has changed throughout history - that is, what a library does and is for, epistemically speaking. Epistemic aims are not often considered in the information field, but recent discussions have called for further exploration of the concept of understanding [3]. Drawing on Heidegger's philosophy of technology, we can say that understanding is inextricable from questioning. To that end, in this paper I reconsider some of the discourse regarding the epistemology of libraries throughout their history in light of understanding and questioning. I suggest that libraries were long conceptualized as cultivators of understanding, but by the 20th century they were conceptualized merely as providers of information. As the internet age continues to unfold, the conceptualization of libraries is beginning to change again. I suggest that we would do well to more concertedly direct these efforts in light of the concept of understanding.

The paper begins with philosophical groundwork, explaining the connection between Heidegger's philosophy of technology, understanding, and the library (section 1). Heidegger suggests that the predominant human orientation toward modern technology is antithetical to genuine human understanding. This is because such technology encourages seeing things for their resource value rather than as wholes. This form of relating can be conceptualized as answering — as seeing only the answer and forgetting about the question and the possibility for other questions [see 16]. A solution, then, is in the kind of technology that facilitates questioning. 
That is, returning to understanding requires questioning. This point leads to an examination of how questioning has been conceptualized in the information field (e.g., anomalous state of knowledge, query formulation) as something undesirable or problematic.

In section 2, we examine the place of questioning in the library, such as in what is now called the reference interview, from Antiquity through the present day. In brief, we see that, originally, libraries privileged intellectual exploration, being exemplars of belonging and understanding. By the early modern period, libraries had begun to be conceptualized as storehouses for books, and the library began to be oriented toward the speedy provision of these books - and soon, of information. In the 19th century, this provision became charged with improving societal productivity; by the mid-1900s, it was predominantly treated as a business transaction. Today, there are signs that the conceptualization of the library may be shifting again; the seeds are in place for a resurgence of questioning, understanding and belonging in the library

—but they will require cultivation.

\section{Questioning, Understanding and Technology}

\subsection{Questioning Technology}

What is technology? Oftentimes, as Alan Kay observed, we tend to assume that technology is "anything that was invented after you were born." But things like libraries and writing systems are technologies, too. So what is technology? 
In “The Question Concerning Technology,” Martin Heidegger (1889-1976) addresses this question [20]. He begins by saying that, in common parlance, we think of technology 1 as a human activity that constitutes a means to an end. This being the case, Heidegger proposes that technology is what brings ends into appearance - which means technology is a kind of revealing. To deepen this view, Heidegger draws on the Ancient Greek concept of poiesis, or bringing-forth, which Heidegger finds to be a more precise way to discuss "revealing." In poiesis, things can be brought forth in themselves (Heidegger gives the example of a flower coming into bloom), or brought forth from outside forces (exemplified by a crafter making a chalice). This bringingforth is a change taking place in the material of the world, where something that was once disparate or hidden comes together in plain view. As Heidegger says, "Bringing-forth brings out of concealment into unconcealment" [20, p. 317]. That is, when a flower blooms or a person makes a chalice, it's not that something is being made from nothing; rather, stuff that's already in the world is being rearranged into a new form. The Greeks called the result aletheia, which literally means "not being hidden," and they saw this as a kind of knowledge or truth. To be sure, it wasn't the same kind of knowledge as facts and historical dates; rather, it had to do with expressing potential and the unity between function and form, rather than having knowledge of facts.

\footnotetext{
${ }^{1}$ Writing in German, Heidegger uses the term Technik in this discussion. It is worth noting that Technik encompasses both technique and technology in English.
} 
Heidegger observed, however, that not all technology engenders this kind of truth. Specifically, he saw something about what he called "modern technology" that seemed to work differently. He writes:

What is modern technology? It too is a revealing [but one that] does not unfold into a bringing-forth in the sense of poiesis. The revealing that rules in modern technology is a challenging, which puts to nature the unreasonable demand that it supply energy which can be extracted and stored as such. [20, p. 320]

Heidegger calls the challenging and demanding of modern technology enframing; through enframing, we see the world as standing-reserve. What this means is that, with modern technology, we see things not in a holistic way, but rather as stocks of resources waiting to be harnessed. In our accounting of beef, for instance, we forget the cow; and in our diligent scheduling, we misapprehend time.

As Heidegger writes, enframing is one way humans can relate to technology. The other, diametrically opposed, is belonging. When a person relates to the world as belonging, the world is revealed as aletheia. As described above, aletheia is an unconcealment. Importantly, in aletheia, though something is revealed, a person still has the sense that something else is left unrevealed, that the world still holds more mystery. The very word unconcealment is meant to remind us of this - the word conceal is still lurking within it. In the novel In Search of Lost Time, Marcel Proust gives a poignant illustration of this interplay between concealment and unconcealment: 
Then ... suddenly a roof, a gleam of sunlight on a stone, the smell of a path would make me stop still, to enjoy the special pleasure that each of them gave me, and also because they appeared to be concealing, beyond what my eyes could see, something which they invited me to come and take but which despite all my efforts I never managed to discover. $[33$, pp. 175-176]

As with Proust's protagonist, through belonging a person is immersed in the mystery of the world. Though a thing's surface has come into unconcealment, its essence is still concealed; by engaging with this mystery, Heidegger says, a person comes closer to the essence.

Here we see the key difference between belonging and enframing. Whereas in belonging a person recognizes that something remains hidden, in enframing a person succumbs to the allure of what has been revealed and forgets about everything else. "Man, thus under way, is continually approaching the brink of the possibility of pursuing and promulgating nothing but what is revealed $\ldots$ and of deriving all his standards on this basis" [20, p. 331]. That is to say, we can become so obsessed with the lumber, pork, schedule or social media profile that we forget that there ever was such a thing as a cow, time, or even personhood.

Heidegger sees enframing as a pernicious danger. Enframing, by definition, blocks out any possibility of belonging. On the other hand, Heidegger notes, belonging can rather easily slip into enframing. Dramatically, Heidegger writes that, when man sees objects not as objects but as standing-reserve, 
then he comes to the very brink of a precipitous fall; that is, he comes to the point where he himself will have to be taken as standing-reserve. Meanwhile, man, precisely as the one so threatened, exalts himself as lord of the earth. [20, p. 332]

In this discussion, Heidegger paints a grim picture of society, and he doesn't seem to have much hope for the future. As he famously remarked in a 1966 interview with German newspaper Der Spiegel, "Only a god can save us." And things don't seem to have much improved. Our seeing the world as standing-reserve has contributed to climate change (and indeed our denial of it), which is devastating and now possibly irreversible. No doubt it also plays a role in the sense of alienation and terrifying displays of violence that pervade contemporary Western society, as described by journalist Sebastian Junger in his book Tribe. For Junger, even the "simple" act of littering is symptomatic: "When you throw trash on the ground, you apparently don't see yourself as truly belonging to the world that you're walking around in" [24, p. 112].

At the end of his essay, Heidegger does admit some hope. Heidegger was fond of repeating a refrain from the poet Friedrich Hölderlin: "Where the danger is, grows the saving power also" [20, p. 333]. Thus Heidegger suggests that technology itself might hold the key to relating to technology as belonging rather than enframing. Recognizing poiesis as the goal, Heidegger suggests that the way forward is in continued questioning. In this light, it seems that a way to promote belonging and minimize enframing is to dig further into questioning itself. How can we develop technology that leads us to question? 


\subsection{Technology and Understanding}

Technology has always been connected to knowing. We humans put knowledge to use in designing, building and using technologies, and through technology we learn new things about the world. As Heidegger writes, the Ancient Greek terms techne and episteme were related, as both are forms of revealing, until Plato argued for their separability [20]. Though all technology may have an epistemic component, the focus here will be on information technologies, which are those which store, process and transmit information.

So we can ask: What is the epistemic aim of information technology? This question does not seem to have been taken up with much seriousness. Generally, we have assumed that information technology provides information — as implied by its name — and the provision of information to people is taken to be tantamount to providing knowledge. Though generally implicit, this is manifest the names of various academic fields, such as knowledge organization and knowledge management. This, in a way, is unsurprising; the field of epistemology itself is generally defined as the study of knowledge.

The connection between information and knowledge, and the relevance of this to the information field, has been formalized in the much-discussed and -criticized pyramid of datainformation-knowledge-wisdom. This pyramid was first proposed by Russell Ackoff as a linear hierarchy wherein faculties of organization, processing and interpretation transform data into, sequentially: information, knowledge, understanding, intelligence and wisdom [1]. (As others adopted this framework, various levels were sloughed off, to the point that today the pyramid is 
best known as DIKW or even simply DIK.) "Each of these includes the categories that fall below it-for example, there can be no wisdom without understanding and no understanding without knowledge" [1, p. 3]. Yet in an analysis of how this hierarchy came to be described in textbooks, Jennifer Rowley finds that there is little consensus regarding the process of transformation between levels in the hierarchy [37]. Indeed, even in Ackoff's original formulation, there is some ambivalence as to whether these epistemic orders unfold in the human mind or if they are descriptions of processes in information systems. This is problematic, for while computers may work through processing data, the human mind certainly doesn't [29]. Another problem is that not every step in the pyramid seems to be based on prior steps [15].

Taking a different approach, Bawden and Robinson have called for a focus on the concept of understanding as an epistemic aim for the information field [3]. They draw inspiration from the term appearing in Ackoff's original formulation of the DIKW pyramid, which has gone unexamined. They note that the concept of understanding is being discussed by contemporary philosophers such as Jonathan Kvanvig, and they seek to integrate these accounts with the philosophy of information championed principally by Luciano Floridi. This discussion surfaces an important observation: Knowledge is not the only possible epistemic aim. Indeed, John Greco argues that what we would call understanding was an important connotation of the Greek word episteme but has been largely ignored by epistemologists. Whereas knowledge implies a simple binary of known/unknown, the concept of understanding recognizes shades of gradation; 
concretely, understanding constitutes the construction of causal relations among distinct pieces of knowledge [18].

The concept of understanding has also been developed in a separate philosophical tradition: hermeneutic phenomenology. Extending the transcendental phenomenology of Husserl, hermeneutic phenomenology originated chiefly with Heidegger, who conceptualizes

understanding as the way a person relates to the world when they are being true to their authentic self [21]. Understanding, at its essence, is a matter of inhabiting one's present situation, interpreting the things one encounters in the world for their relevance and usefulness for carrying oneself forward. This sort of understanding is ontological understanding, or the mode of being that makes possible the "knowledge-related" form of understanding described previously, which can be termed ontic understanding [17].

To the extent that understanding has been conceptualized at all within the purview of epistemology, its conceptualization has been primarily linguistic. The doctoral dissertation of Patrick Wilson seems to have been the earliest epistemological focus on the concept of understanding, and it was rooted in the Anglo-American tradition of philosophy of language [52]. Even despite its apparently recent explicit origins, the concept of understanding has implicitly underpinned the information field since the libraries of Antiquity, as we shall see in Part Two. Fittingly, Wilson went on to be a foundational information scientist, lending further credence to the importance of the concept of understanding to the information field. Wilson's articulation of understanding applies to linguistic communication; it attempts to account for the 
reality that humans can make sense of each other's utterances. This may seem, at first, a bit pedantic. What question could there be about understanding what other people are saying? Yet, as Wilson shows, our everyday conversations are less a matter of us passing around well-formed meanings and more one of constant negotiation. Wilson's main innovation was in recognizing all meaning as context-dependent and contingent rather than "stored" in words. Wilson gives the example of a person following a recipe that says, "Put in two cups of milk" [52, p. 35]. Immediately, in our culture and with a requisite level of experience, we know exactly what this means: There is a unit of measure called a cup, and the recipe is calling for twice this amount to be added. But that meaning is not explicated in the given words. Would a person not also be following the directions if they took two 14-ounce glasses full of milk and put them in the cabinet? In a sense, they would, as this action does correspond to a possible meaning of those words; but for practical purposes, as defined by the contingency of this situation, they would not. Today we readily attribute this insight to Ludwig Wittgenstein and his concept of the languagegame [53]; but Wilson is worth remembering in this regard, as he made this contribution independently and went on to play an important part in the information field.

Still, there is more to understanding than linguistic accounts can allow. A satisfactory account of human understanding, then, must go deeper than language alone. The sort of understanding developed by Heidegger and later hermeneutic phenomenologists provides such an account. As described above, Heidegger's concept of understanding involves a person's embodied action as part of a world of things. This view was developed more fully by Maurice 
Merleau-Ponty [30], who sought to describe how the human body plays into their experience of understanding. More recently, though a bit outside the phenomenological tradition, Mark Johnson has developed an account of how the body plays a primary, originary role in human understanding [23]. As Johnson argues, the things we refer to as "mind" and "body" are not two separate things, but rather aspects of an organic process in which all meaning, thought and language emerge from dimensions of embodied activity.

Understanding arises and is built as a person makes connections among images, contours of affect, qualities, memories, perceptions, etc. Meaning, in this view, does not depend on the possibility for something to be formulated in words - rather, we can grasp meanings in felt, embodied ways. This means that knowledge and understanding are fundamentally visceral and embodied in our physical engagement with the world; only after this can they be abstracted into conceptual terms.

If we are suggesting that understanding is the proper epistemic aim of technology, particularly information technology, then questions are raised about the limitations of technologies that were not developed with this end in mind. By and large, modern information technology seems to favor answer-provision over question-provocation. As a result, modern technologies provide us with information — perhaps even knowledge — but they may not do all they could to foster understanding. Surely this doesn't need to be the case. Perhaps technologies can be developed for questioning and consequently the facilitation of understanding. 
Above, I proposed that understanding and questioning are inextricable. A lack of understanding, then, implies an attendant lack of questioning. This may be at the root of some of our society's problems. I am, by far, not the first to suggest this: Commenting on his society's apparent inability to question deeply, Zhuangzi wrote, in 4th-century-BC China, "Everyone in the world knows how to raise questions about what they don't know, but none know how to raise questions about what they already know. ... This is the reason for the great disorder" [47, p. 66]. If we are to follow this wisdom, then, it would seem that learning better to question-to question technology in particular - may pave the way for improvements in society. In this vein, and much

more recently, journalist Warren Berger explores the role of questioning in creativity and innovation, concluding that we are in need of question-inducing techniques and technologies [4]. I would suggest that the information field has a central role to play in building that path.

\subsection{Understanding Questioning}

In the previous section, I argued that we must conceptualize understanding as something that is not rooted in language, but rather the other way around. Because understanding and questioning are inextricable, we must also work to conceptualize questioning as something prior to language. In this section, we will consider how questioning has been thought of in the information field and work toward such a prelinguistic view of questioning.

The information field has long considered questioning, and for a practical reason: People seek information by asking questions. In a library, a visitor may ask for materials on a particular 
topic or in response to a particular problem (human processing); online, a person may ask a search engine for answers to a given topic or query (machine processing) [see 50]. As it stands, though information scientists have always recognized questioning as part and parcel to their work, there has been little conceptual theorization around questioning. Keith Swigger reviewed the literature on questions in library and information science and found that, instead, research related to questioning has actually focused instead on problem-solving and decision-making, assuming the concept of questioning to be non-problematic [43]. Swigger suggested that this lack of theorization could be at the root of stagnation in the technological development of information retrieval, which could be stoked anew by fresh theory. A serious declaration; however, it wasn't until much more recently that Swigger's observation was taken seriously.

Hannah Kwon, in her doctoral dissertation, presents a review of the information science literature on questioning [26], updating Swigger's work. Kwon shows that research on questioning has conceptualized a question primarily in two ways: as an object that can be conveyed through information transfer; and as a sign of an information seeker's "problematic situation" [51]. Research of the first sort has focused on subject matter, grammatical formulations and classifying queries in order to improve the design of information retrieval systems, which respond to people's questions by selecting relevant documents from a set of candidates. "The goal is to build more efficient information systems, but in taking the question at face value, the complexity of questioners' cognitive processes of formulating and asking questions is overlooked" [26, p. 27]. Research of the second sort, focusing on questioning as an 
individual's mental activity, has focused on tactics for clarifying people's queries to get at the "correct" information to respond to their "visceral need" [44]. In Kwon's view, this research has seen questioning as something fundamentally outward-facing, though malleable. Kwon suggests that research on questioning has been limited by the so-called paradox of the question [14]: that in order to ask a question, a person must know what they don't know.

To surmount this paradox, Kwon sees an opportunity to conceptualize questioning in a third way: as an intersubjective practice, wherein questions are not construed as negative or problematic, but rather as practices rooted in social norms within knowledge domains. Through proposing the view of questioning in this paradigm, Kwon conceptualizes questioning not according to the paradigms of earlier research, but rather as an intersubjective, dialogic practice in accordance with collectivism and social epistemology. Through her analysis, Kwon argues that questions do not simply ask for information, but they also provide information by showing what the asker already knows or assumes and supplying certain criteria for an appropriate answer. Questions, in this light, are contextual and contingent. As she shows, questions are formulated in different ways in different knowledge domains. That is, even when considering the same topic, neuroscientists and computer engineers ask different questions and ask them differently. Kwon's investigation only considers linguistic questions, which, in light of the foregoing discussion, is a serious limitation. If understanding encompasses more than merely the linguistic, and if questioning builds understanding, then there must be a way of questioning that does not depend on language. 
Fortunately, though Kwon does not attempt to conceptualize such a way of questioning, her analysis gives some headway. She allows that all statements imply a correlated question, concluding that all statements entail unarticulated questions. The insight that all pieces of knowledge have a corresponding question has been a cornerstone of question theory since the philosopher R. G. Collingwood, who was the first to gesture toward a theory of questioning, proposed it [9]. On this view, a question can be inferred from a knowledge statement (a la Jeopardy). Robinson and Rackstraw, too, recognize implicit questions in their seminal taxonomy of questions, though they too focus on linguistic questions [36]. They even acknowledge the existence of implicit non-verbal questions, which at first blush may seem to constitute a form of questioning outside language; however, as Robinson and Rackstraw conceptualize them, such implicit questions are in the end articulable in words.

In order to fully escape the confines of language, we must develop a much broader view of what a "knowledge statement" is. As Johnson has shown, knowledge is, at its root, not linguistic; rather, knowledge is rooted in embodied being [23]. But even allowing this, one might argue that all knowledge can be put in propositional form. Johnson denies this, along with a number of other thinkers. Max van Manen, for instance, bifurcates human knowledge into the gnostic and pathic [47]. Gnostic knowledge is procedural and conceptual— the knowledge of "facts"- whereas pathic knowledge is emotional and embodied. Pathic knowledge is, simply, the felt sense of being alive in the world; it is relational, situated and enactive. This is the knowledge of aletheia, described above. An example of pathic knowledge is knowing how to play a violin, 
ride a bike or cook a paella. It should be noted that gnostic knowledge can be about pathic knowledge, but it is not pathic knowledge in itself. For instance, a person can talk about how they play the violin, but these verbal statements are fundamentally different from the playing of the violin.

On the view of pathic knowledge, things in themselves are knowledge "statements" of themselves. We can recall again Proust's description of his protagonist's walk from his house in provincial France, cited earlier. The sight of the roof, the way the sun falls on the stone and the smell of the flowers all constitute statements of pathic knowledge. But though we talk about them in words, it is important to remember that statements about these things are not the same as the things themselves; statements can, arguably, evoke the things, but they do not capture them. Now, recalling that all statements imply a correlated question, we can think of all ways of being as having a question correlate. Just as conceptual knowledge is built up and abstracted from embodied knowledge, so verbalized questions are built up and abstracted from these primordial, being-based questions.

Moreover, this shows how some propositionally-formed "questions" may not truly be questions after all. For instance, in American culture we often "ask" how people are when we see them, without expecting or wanting an answer. In these cases, we are not really asking a question; we are simply performing a cultural script, even though the form of that performance is ostensibly a question. 
A question, then, is simply a way of orienting oneself to the world: A question is an open way of being. It is a mode of bringing what one already is toward the unknown. Indeed, one can live their life in a questioning way; Rainer Maria Rilke even suggested in his Letters to a Young Poet that this is requisite for success as a poet: living and loving the question [35]. This, it turns out, leads us back to Heidegger's concept of belonging, which is a fundamentally poetic way of relating to the world, i.e., an open and questioning way of being.

Zhuangzi wrote that our failure to question is the reason for the "great disorder." Heidegger, too, wrote that "questioning is the piety of thought" [20, p. 341]. In order to improve society, in order to understand, in order to overcome the allure of enframing in our predominant way of coming to modern technology... we must be questioning.

\section{Questioning and Understanding in the Library}

The previous section foregrounded the tension between information and understanding (as answering and questioning) — which is a special case of the tension between Heidegger's concepts of enframing and belonging. We will now move from the realm of theory to a practical site of information dealings: the library. In this section, we will consider the historical trajectory of the library as an institution by focusing on the place of questioning in the library.

To begin with, what is a library? In today's climate of rapid technological change, it may seem that this question is being asked more than ever; on the contrary, it seems that this question has been posed since the first library was born. And indeed there are as many answers to that 
question as there are people asking it, as we will see below. For now, it will suffice to make the point that a library is a kind of technology (recalling Heidegger's definition of the term), i.e., a human-directed revealing. As such, we can, as an exercise, connect the historical trajectory of the library to Heidegger's historical trajectory of technology.

The history of libraries extends as far back as the history of civilization itself, beginning in the Ancient Near East and extending around the world as the centuries unfolded. To be sure, it is inappropriate to impose contemporary notions of what a library is onto earlier eras. And regarding ancient times, our knowledge of how texts were actually used is severely limited. Still, the scholarship on these issues seems to suggest that libraries were once inextricable from schools, and as such were prime sites for intellectual exploration and questioning — in Heideggerian terms, belonging. In the Middle Ages, the library was beginning to be conceived predominantly as simply a collection of books, a conceptualization that gradually sharpened and persists to this day. Consequently, libraries moved from being sites of belonging to being sites of enframing - that is, their focus moved from provoking questions in patrons to providing answers to patrons. The transition was hastened with the public library movement, through which libraries became vehicles for increasing the productivity of citizens. Over the following century, the business of the library came to be just that — a business — and the questioning that occurred inside libraries was conceptualized as a business transaction. Today, with the availability of the world wide web for people's fact-finding, the dominant conceptualization of the library may be changing again. Following Heidegger's suggestion that the way forward is to develop technology 
that leads us to question, we can consider how the changing library is poised to become such a technology.

The following sections explore this historical path. As secondary research, this review relies on the scholarship of others and is not comprehensive. The purpose of this review is primarily to spark thinking and further research on these topics - to promote questioning, as it were.

\subsection{The Ancient Library}

When we think of ancient libraries, often the first to come to mind is the Great Library of Alexandria, which has been much researched and, indeed, mythologized. There were many more ancient libraries besides the one at Alexandria (which itself actually comprised two locations), and considering the nature of these other libraries, we can get a better view of the nature of the ancient library.

In a historical survey of libraries in the ancient world, Lionel Casson describes the world's first libraries: They were collections of clay tablets inscribed in cuneiform with, predominantly, commercial records, which were stored in temple rooms in Sumer [8]. Some of these collections date back to 2,600 B.C. As this suggests, for Casson, a library is merely a collection of texts. As will become clear further on, Casson has analyzed the ancient library based on a modern conception of what the library is. In this way, though his work presents 
admirable scholarship about book collections and manufacturing in ancient times, it doesn't go far enough to illuminate the ancient library.

For this, we can turn to Yun Lee Too's work, which explicitly challenges the assumption 'that the collecting of physical texts, whether the 'scroll' or 'book' or, later, the codex, is a significant raison d'etre" of the library [45, p. 3]. To be fair, this assumption can be forgiven; etymologically, the word library itself literally means "bookshelf." However, Too points out that many library historians make the further assumption that the purpose of a library is to preserve books, even to the point of making them inaccessible. In contrast, Too argues that the ancient library was much more than just a receptacle for scrolls. Too makes the point that "it is the presence of the physical book, rather than the book itself, that is important, for it produces a site of intellectual foment" [45, p. 6]. For Too, the term library constitutes not just a collection of texts, but also a way of understanding that collection of texts as an institution. In this way, the notion of the library must include the people who use the library and how they use it, beyond just the texts themselves. Indeed, Too argues that in many cases ancient libraries were not navigable without the coexistence and assistance of a librarian who intimately knew the collection; the librarian required the library, and vice versa. Moreover, Too presents some examples of people who are libraries, which were called "breathing libraries" [45, p. 84], i.e., those who had committed to memory extensive texts and could marshal their contents in conversations.

Though breathing libraries functioned with the memory of educated people, being a library was much more than rote memorization. To be sure, memorization was a necessary 
element, but it was not sufficient. Consider, for instance, the rhapsodes. These were traveling performers who recited epic poems, particularly those by Homer, from memory. Though this may seem astounding, the historian Xenophon suggests that rhapsodes could be rather stupid, memorization notwithstanding [45; see also 49]. True learning, in other words, involves some memorization, but it also involves understanding — that is, being able to link what was memorized to other aspects of lived experience — and thus questioning, i.e., being able to bring all this forward into new situations.

So, on Too's account, the ancient library was not just a way to provide access to particular texts, but also a way to facilitate understanding and learning through those texts. The

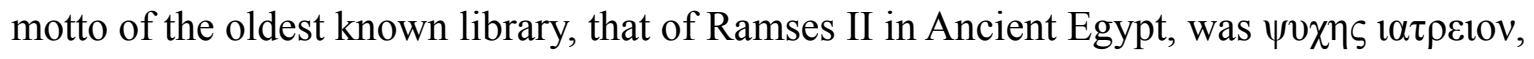
"house for healing the soul," and this motto echoed throughout the ancient world [27]. The features of the ancient library come through most clearly in the example of the Library of Alexandria, which was inspired by Aristotle's Peripatetic School and consequently became known as one of many peripatetic libraries. The term peripatetic comes from the ancient Greek word peripatetikos, which means "walking around." Notably, the library was not a standalone institution; it was part of the Museion Academy, which was a physical campus that housed a community of scholars. As such, the Great Library was perhaps more akin to a modern-day academic library than a public library. The academy complex was laid out with a network of paths, colonnades and courtyards, with botanical gardens and other displays meant to inspire and delight, such that the design afforded and encouraged movement. That is, the peripatetic library 
was a site for walking around, both physically and intellectually. Like Aristotle's school, the activity of the peripatetic library was to collect and interpret texts in all fields of scholarship, which unfolded through the discussions of scholars who gathered there, contributing to the formation of their souls [41].

Such were the libraries of the ancient world: the libraries of schools, in which documents, people and activities were co-constitutive and therefore inextricable. As the centuries progressed, the monastic library was born; these libraries were bastions of intellect in the so-called "dark ages," and, indeed, as historian Kenneth Setton describes, they too were generally connected with educational institutions [40].

Gradually, the innumerable, nuanced dialects of civilization were collapsed into the languages of nation-states with standardized written forms; literacy increased; and technological advances made the reproduction of texts faster and cheaper, culminating in the birth of the printing press in the mid-fifteenth century. Along the way, the popular conception of the library shifted from including people and activities as basic elements to considering only texts.

The technological change, as they always do, forced people to grapple with the issues that came about because of it. In the case of the printing press, what ensued was a wider availability of texts than ever before, consequently bringing the text and its management into the foreground, dominating the conceptualization of the library that persists to the present day. 


\subsection{The Early Modern Library}

By the 17th century, it seems that libraries were so text-centric that they valued preservation above access. This was the lament of Richard Bentley (1662-1742), a classics scholar at Cambridge. As described by Matthew Battles, Bentley dreamt of a library that rivaled those scholarly institutions of antiquity: "Even the Vatican Library was not such an institution, for though truly vast, its collection was at this time all but unavailable for true scholarly work. [It] was frequently closed for feasts and holidays" [2, p. 94]. Fortunately, Bentley was charged with restoring the British Royal Library to grandeur, which gave him a channel to realize the library of his dreams, a center for intellectual activity. This was the precursor for what would become the public library movement, providing access to books for every person.

These books, to be sure, were thought to embody intellectual exchange. To read a book was to inhabit a series of conversations of long ago or far away, including the attendant questions and answers. In a Western tradition reaching back to Antiquity, books were conceptualized as friends, as Day describes [11]. Consequently, libraries were characterized "as places where human interpretative understanding and self-understanding takes place — in other words, libraries become sites for understanding (and therefore friendship) between peoples (and for individuals understanding themselves, as well)" [11, p. 15]. To the extent that this was still the case at the outset of the modern era, it was already beginning to fade. Texts are not friends in the same way that other humans are, given that with texts "the speaker always gives one unvarying 
answer" [32, p. 88], and so as the library came to focus more on texts and less on people, the friendships and understanding that the library afforded progressively became impoverished.

One of the factors in this impoverishment, as mentioned in the previous section, was the growing influx of books that came with the spread of printing technology. Pertti Vakkari describes what occurred as the move from the "living" library to a "dead" one [46]. Facing an ever-growing amount of books, it was no longer possible for anyone, even a librarian, to master a collection. Whereas the librarian at Alexandria could, if we are to take historical accounts at face value, memorize many works and at least be familiar with the entirety of the collection, the modern librarian could never hope to do so. Vakkari notes that the historia litteraria, which originally provided substantial summaries of books, could no longer keep up. In effect, annotated bibliographies became mere reference lists; the living became dead. In this way the profession of librarianship shifted from being a "breathing library," as in Antiquity, to mastering techniques for creating non-breathing libraries in the form of catalogues. Intimately understanding every text was now clearly out of reach, and it was all one could do to organize texts so that particular ones could be retrieved when they were needed. Rather than understanding, the librarian was forced to settle for knowing about, and soon this became, in large part, knowing how to navigate the catalogue.

Thus, gradually, the library shifted from being a place where people engaged with other people and books in a questioning way, to places where people came to retrieve books on particular topics. In my view, in this shift, the focus moved from questioning to answering, 
which was predicated on the basis that answering is more societally valuable than questioning. This is not to say that knowing about and locating texts does not play a role in understanding, and nor do I contend that libraries at this time did not contribute to understanding. Rather, I suggest that the focus shifted — the way libraries were talked about and conceptualized—which was related to a shift in the sensed value and ultimately the power of libraries.

Something of a flourish occurred in this dynamic as the public library movement unfolded. Beginning in the 19th century, the library became a site for social reform. Commenting on this, John Stuart Mill found public libraries to be critical in educating the public, in concert with technical education, so as "not to improve them as workmen merely, but as human beings" [31, p. 378]. This would increase their overall happiness, which in his philosophy of utilitarianism was the chief aim. In this clime, libraries were charged with guiding readers to the books that would make them efficient and productive members of society [2]. However, the relationship between librarian and public was still colored by enframing, given the focus on efficiency and productivity. More and more strongly this became the case, such that by the late 19th century, librarians had come to think of their purpose as, primarily, satisfying the needs of their publics. At the first meeting of the American Library Association in 1876, for instance, there was much discussion on how librarians could guide the uninformed masses to the books that they "ought" to be reading, thereby assuaging needs that were still unacknowledged. At the same time, for the sake of efficiency, efforts were being made to help people help themselves (once appropriately educated), in the form of ever-more-sophisticated catalogs and the first open 
stacks [7]. In the modern area, librarians came to see themselves as shepherds, leading their publics to their best selves. Societally, it seems that what "best" and "improvement" mean has shifted from something deeper-rich understanding — to something shallower: economic productivity.

\subsection{The 20th-Century Library}

Comparing the 20th-century library to the libraries of earlier eras, one finds many of the same elements. There are books, in one form or another, which are arranged according to some system, and there are spaces for reading, personnel and some decorations. But there are, of course, numerous differences. Reading Setton's chronicle of the evolution from the medieval to modern library, the most striking change is the speed with which libraries operate. Setton writes, for example, of Anthony Panizzi, who became known for implementing the cataloging system in the library of the British Museum in the early 1800's:

Panizzi claimed that almost any book could be put into the hands of a reader in five minutes, wherever it might repose on more than a dozen miles of shelving! (253). In most libraries on the continent the reader made his desires known on one day, and returned the next to consult books which as often as not the librarians could not find. [40, p. 385] Panizzi's system suffered many critics; it was pedantic and verbose to the point that it soon became impractical and could not be employed in other libraries. In any case, it forms an important showing in the history of cataloging and demonstrates that libraries have had an explicit and conscious intent to increase the speed with which they provide their services. As 
libraries moved into the 20th century, these efforts were supported by other societal changes, such as the advent of telecommunications and computing. The apotheosis of speediness was complete, perhaps, when it was reified as one of S. R. Ranganathan's five laws of library science: "Save the time of the reader" [34, p. 337].

Relatedly, it was around this time that the modern concept of information was born. As Day writes, information referred to a process rather than a thing until very recently [10]. Before, the term denoted the act of sharing some knowledge with someone, which is by its nature a multifaceted and context-dependent process. Now, information came to be conceptualized as the epistemic content held within books and other objects. For libraries, the subtext came to be that it was the information that book-seekers were really after, rather than the books themselves, and rather than particular sorts of interaction with the books. Libraries came to see themselves as providers of information as a thing, rather than facilitators of information as a process. The difference may seem slight; however, as Day writes, this trend toward epistemic fragmentation continues to progress, leading to evisceration and impoverishment in other areas of life: It has been detrimental to scholarship, as "sources" are invoked in passing as evidence rather than engaged with in critical dialog, and it has also engendered, for instance, "the generalization and dissolution of the notion of "friends"' $[11$, p. 20] in the age of Facebook. To speak solely of library practice itself, Vesa Suominen argues that the adoption of the concept of information led libraries to assess their performance through short-term use indicators, and consequently librarianship became merely a technical routine [42]. 
One place this is clearly visible, and where the theme of questioning comes into clear focus, is in the reference interview. Discussions on the topic began in 1876 in a paper by Samuel Green, who pointed out that library users often need help clarifying their needs, navigating the catalog, retrieving the items, and the like [19]. Green draws four conclusions: First, a pleasant demeanor helps in satisfying information needs; second, the librarian's judgment can be used in maintaining a collection; third, the librarian should get to know their public intimately and seek to help them in any way possible; and fourth, many different sorts of people use the same library. Two decades later, Elizabeth Woodruff articulated an additional insight:

And right here lies the opportunity for the exercise of one of the greatest gifts of the successful librarian — the ability by skillful questioning, without appearance of curiosity or impertinence, to extract from the vaguest, most general requests, a clear idea of what the enquirer really needs. [54, p. 67]

Even today, this remains the crux of the reference interview, as can be seen in a typical textbook definition of the term:

The reference interview is a dialogue between the user and librarian in which the librarian's objective is clarification and understanding of the user's question as a means to meet the user's information need, and the user's objective is to have the librarian understand and meet the information need. [5, p. 57]

Since Woodruff's time, discussion has proliferated on the best way to achieve this—and to train librarians to do it. Charles Bunge offers a thorough historical review of this work [7]. 
Of particular note is the work of Robert Taylor [44], which characterized the library visitor's precise but unarticulated question as their "visceral need," saying that it is the librarian's job to surface and address that need. To do this, the librarian and the visitor must go through a process of question-negotiation, through which the librarian can determine the visitor's subject of interest, motivation, personal characteristics and preferences, as well as the anticipated structure of possible answers. As Taylor says, the success of this negotiation process requires time and, critically, relies on a rich interpersonal relationship — the longer established and deeper, the better. Taylor notes, however, that librarians are strapped for time and have not always cultivated these strong relationships, and so tend to be more focused on "the static content of reference collections and classification systems" rather than "the dynamism of communication" [44, p. 191].

Mary Lynch made similar observations in the following decade, arguing that, ultimately, the reference desk is physically organized against the time-consuming, possibly-revealing process of question-negotiation, coercing instead quick answers to superficial questions. Lynch writes:

Although the reference interview is conducted by a person whose knowledge base and other characteristics may entitle him or her to the title of professional, the context of the reference interview makes it resemble the interview of a sales clerk rather than the interview of the physician or attorney or personnel office. ... Perhaps library users would be better served by a different arrangement. [28, p. 137] 
Thus, the literature on the reference interview calls for an approach based on questioning, dialogue and belonging (i.e., cultivating understanding), but this does not seem to have been borne out in practice. As much as librarians might have strived for the understanding mode of reference service, the shape of the 20th-century library came to be optimized against it. I would suggest that one reason for this may be the dominant conceptualization of the reference interview as a technical process for alleviating a user's information need.

Indeed, Courtney Selby [38] outlines the evolution of the reference interview throughout the 20th century and concludes that, although the specific forms of the reference interview have changed over the years - including telephone, in-person and online-its essential nature of addressing information needs has persisted. In the reference interview, satisfying the information need is conceptualized as the ultimate goal of the librarian. In other words, the person has a question, and the librarian will provide an answer.

In this climate, the library becomes a business, as Lynch hinted at in the excerpt quoted above. Taylor, too, draws an analogy of different types of libraries as "wholesalers" and "retailers" [44, p. 194]. And finally, since the 1990s, there has been a trend for libraries to refer to their publics as "customers," reflecting the conception that libraries are a business that trades in the commodity of information [6,22].

\subsection{The Present and Future Library}


The trajectory of the library from Antiquity to the 20th century can be read as a movement from belonging to enframing [20]—from a "house for healing the soul" [27] to a business, from a place for questioning to a place for getting answers, from a site for understanding to one of information. In enframing, information is stockpiled; the sense is that knowledge can be controlled, just as knowledge is used as a means of commanding and controlling nature. Instead of being sites of open-ended wondering and leisure, libraries came to be conceptualized as places for getting information and improving oneself along specific dimensions (increased salary, etc.). This is not to say that no wondering, questioning or leisure occurred in libraries in the 20th century. For instance, fiction (and later music and movies) have long been circulating in public libraries. Nor is it the case that knowledge-as-command didn't exist in the ancient world. Rather, it is a question of focus; the dominant conceptualization of the library has become one of enframing, and its computer systems and physical arrangement further compels such enframing.

What does the future hold? Recall Hölderlin's refrain, "Where the danger is grows the saving power also" [20, p. 333]. For one, much of the technology in and related to libraries, such as citation indexes and catalogues, could be put into the service of understanding with the proper interfaces. Such work may be particularly useful today: In the age of Google and ubiquitous computing, fewer people use libraries for fact-finding. Other purposes for the library are beginning to enter the social consciousness. For instance, Eric Klinenberg has recently written on the role of libraries as social infrastructure [25]. Libraries are serving as community meeting places, offering wide swaths of programming, from knitting to meditation - treating the whole 
person, rather than just the intellect. Current research is positioning the reference interview as a site for learning, teaching and understanding, rather than merely the provision of information $[12,13,48]$. Relatedly, there has also been a resurgence of thinking about questioning in the popular business literature $[4,39]$.

So a new epistemology of the library seems to be emerging. The situation is prime for libraries to reorient themselves toward the epistemic aim of understanding, which involves questioning, belonging, and being open to multiple perspectives. But change is slow in some quarters. As sci-fi author William Gibson was famous for saying, "The future is already hereit's just not very evenly distributed." I would suggest that an understanding of the historical trajectory presented here gives a chance for current efforts to be strengthened, for that change to come more consciously and broadly. 


\section{References}

[1] Ackoff, R.L. (1989). From data to wisdom. Journal of Applied Systems Analysis, 15(1), 3-9.

[2] Battles, M. (2015). Library: An unquiet history (reissue). New York: W. W. Norton.

[3] Bawden, D., and Robinson, L. (2016). “A different kind of knowing”: speculations on understanding in light of the philosophy of information. Paper presented at Conceptions of Library and Information Science 9, Uppsala, Sweden. Retrieved from http:// openaccess.city.ac.uk/id/eprint/14994

[4] Berger, W. (2014). A more beautiful question: The power of inquiry to spark breakthrough ideas. New York: Bloomsbury.

[5] Bopp, R. E., \& Smith, L. C. (2011). Reference and information services (4th ed.). Santa Barbara, CA: Libraries Unlimited.

[6] Budd, J. M. (1997). A critique of customer and commodity. College \& Research Libraries, 58(4), 309-320.

[7] Bunge, C. A. (1984). Interpersonal dimensions of the reference interview: A historical review of the literature. Drexel Library Quarterly, 20(2), 4-23.

[8] Casson, L. (2002). Libraries in the ancient world. New Haven, CT: Yale University Press.

[9] Collingwood, R. G. (1939). An autobiography. Oxford: Oxford University Press.

[10] Day, R. E. (2001). The modern invention of information: Discourse, history, and power. Carbondale: Southern Illinois University Press. 
[11] Day, R. E. (2014). Indexing it all: The subject in the age of documentation, information, and data. Cambridge, MA: The MIT Press.

[12] Ellis, L. A. (2004). Approaches to teaching through digital reference. Reference Services Review, 32(2), 103-119

[13] Elmborg, J. (2002). Teaching at the desk: Toward a reference pedagogy. Portal: Libraries and the Academy, 2(3), 455-464.

[14] Flammer, A. (1981). Towards a theory of question asking. Psychological Research, 43, 407-420.

[15] Frické, M. (2009). The knowledge pyramid: a critique of the DIKW hierarchy. Journal of Information Science, 35(2), 131-142.

[16] Gorichanaz, T. (2016). Gauguin's savage document work: Understanding as function. Proceedings from the Document Academy, 3(2), Article 5. Retrieved from http:// ideaexchange.uakron.edu/docam/vol3/iss $2 / 5 /$

[17] Gorichanaz, T. (2017). Applied epistemology and understanding in information studies. Information Research, 22(4), paper 776. Retrieved from http://InformationR.net/ir/22-4/ paper776.html

[18] Greco, J. (2014). Episteme: knowledge and understanding. In K. Timpe and C. E. Boyd (Eds.), Virtues and their vices (pp. 285-301). Oxford, UK: Oxford University Press.

[19] Green, S. S. (1876). Personal relations between librarians and readers. American Library Journal, 1(2), 74-81. 
[20] Heidegger, M. (1977). The question concerning technology. In D. F. Krell (Ed.), Basic writings (pp. 307-341). New York: HarperCollins. (Original work published 1954)

[21] Heidegger, M. (2010). Being and time (J. Stambaugh, Trans.). Albany: State University of New York Press. (Original work published 1932)

[22] Johannsen, C. G. (2015). Library user metaphors and services: How librarians look at their users. Berlin, Germany: De Gruyter Saur.

[23] Johnson, M. (2007). The meaning of the body: Aesthetics of human understanding. Chicago, IL: University of Chicago Press.

[24] Junger, S. (2016). Tribe: On homecoming and belonging. New York: Twelve.

[25] Klinenberg, E. (2018). Palaces for the people: How social infrastructure can help fight inequality, polarization, and the decline of civic life. New York: Crown.

[26] Kwon, H. (2016). On the social epistemological nature of questions: A comparison of knowledge domains' question formulations on the topic of "memory" [Unpublished Ph.D. dissertation]. New Brunswick, NJ: Rutgers.

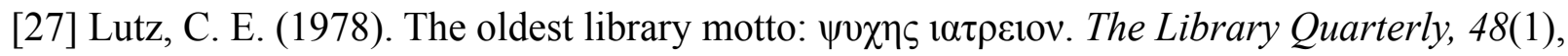
$36-39$.

[28] Lynch, M. J. (1978). Reference interviews in public libraries. The Library Quarterly, 48(2), $119-142$. 
[29] Ma, L. (2012). Meanings of information: the assumptions and research consequences of three foundational LIS theories. Journal of the Association for Information Science and Technology, 63(4), 716-727.

[30] Merleau-Ponty, M. (2012). Phenomenology of perception (D. A. Landes, Trans.). Oxon, UK: Routledge. (Original work published 1962)

[31] Mill, J. S. (1967). The claims of labour. In J. M. Robson (Ed.), The collected works of John Stuart Mill, volume IV-Essays on economics and society part I (pp. 363-390). Toronto: University of Toronto Press. (Original work published 1845)

[32] Plato. (1993). Symposium and Phaedrus (B. Jowett, Trans.). New York: Dover.

[33] Proust, M. (2000). Swann's way (In search of lost time, volume one) (C. K. S. Moncrieff, T. Kilmartin, \& D. J. Enright, Trans.). London: The Folio Society. (Original work published 1913)

[34] Ranganathan, S. R. (1931). The five laws of library science. London: Edward Goldston.

[35] Rilke, R. M. (2004). Letters to a young poet (M. D. H. Norton, Trans.). New York: W. W. Norton \& Company.

[36] Robinson, W. P, \& Rackstraw, S. J. (1972). A question of answers. London: Routledge \& Kegan.

[37] Rowley, J. (2007). The wisdom hierarchy: representations of the DIKW hierarchy. Journal of Information Science, 33(2), 163-180. 
[38] Selby, C. L. (2007). The evolution of the reference interview. Legal Reference Services Quarterly, 26(1-2), 35-46.

[39] Sesno, F. (2017). Ask more: The power of questions to open doors, uncover solutions, and spark change. New York: AMACOM.

[40] Setton, K. M. (1960). From medieval to modern library. Proceedings of the American Philosophical Society, 104(4), 371-390.

[41] Sharples, R. W. (1999). The peripatetic school. In D. Furley (Ed.), From Aristotle to Augustine (Routledge history of philosophy, volume II) (pp. 147-187). New York: Routledge.

[42] Suominen, V. (2016). About and on behalf of scriptum est: The literary, bibliographic, and educational rationality sui generis of the library and librarianship on the top of what literature has produced. Oulu, Finland: University of Oulu.

[43] Swigger, K. (1985). Questions in library and information science. Library and Information Science Research, 7, 429-383.

[44] Taylor, R. S. (1968). Question-negotiation and information seeking in libraries. College \& Research Libraries, 29(3), 178-194.

[45] Too, Y. L. (2010). The idea of the library in the ancient world. Oxford: Oxford University Press.

[46] Vakkari, P. (1991). Reading, knowledge of books, and libraries as a basis for the conception of scholarship in Eighteenth Century Germany. Library and Culture, 26(1), 66-86. 
[47] Van Manen, M. (2014). Phenomenology of practice: Meaning-giving methods in phenomenological research and writing. Walnut Creek, CA: Left Coast Press.

[48] Ward, D. (2011). Expanding the reference vocabulary. Reference Services Review, 39(1), $167-180$.

[49] Warner, J. (2001). Information, knowledge, text. Lanham, MD: Scarecrow Press.

[50] Warner, J. (2010). Human information retrieval. Cambridge, MA: The MIT Press.

[51] Wersig, G. (1979). The problematic situation as basic concept of information science in the framework of the social sciences. In Theoretical problems for informatics: New trends in informatics and its terminology (pp. 48-57). Moscow, Russia: International Federation for Documentation.

[52] Wilson, P. (1960). On interpretation and understanding [Unpublished doctoral dissertation]. Berkeley: University of California.

[53] Wittgenstein, L. (2009). Philosophical investigations (4th ed.) (G.E.M. Anscombe, P. M. S. Hacker, \& J. Schulte, Trans.). Oxford, UK: Wiley-Blackwell. (Original work published 1953)

[54] Woodruff, E. B. (1897). Reference work. Library Journal, 22, 65-67. 